\title{
International Law and the Use of Force: The Jus Ad Bellum
}

\author{
by Michael N. Schmitt*
}

Until the twentieth century, no express prohibition against the use of force existed in international law. However, the legitimacy of armed conflict has been an issue of concern since ancient times. Most significantly, the just war doctrine, which was influenced heavily by the writings of Saint Augustine and Saint Thomas Aquinas, characterized armed conflict in terms of right and wrong, morality and immorality. For Augustine, writing in the fifth century A.D., just wars were those that "avenge[d] injuries, when the nation or city against which warlike action is to be directed has neglected either to punish wrongs committed by its own citizens or to restore what has been unjustly taken by it." 1850 years later, Aquinas refined this standard by suggesting three criteria with which to assess the use of force. To be just, the use of armed force had to be authorized by the sovereign, be for a just cause (i.e., the other side must have committed a wrong), and the belligerent nation or city had to posses the "right intention," specifically, "the advancement of good, or the avoidance of evil."2

Writers from the thirteenth to the seventeenth centuries built on the works of Augustine and Aquinas, but continued to address just war in its theological context. By the sixteenth century, however, the classic formulation of the doctrine was under challenge. Typical was Machiavelli's celebrated pronouncement: "that war is just which is necessary."3

With the end of the religious wars and advent of the modern nationstate system, marked historically by the 1648 Treaty of Westphalia, the just war doctrine fell into desuetude. Positivism, an approach to norms based on the practices of states (including agreements between them), emerged to replace it. Its foundational principle, sovereignty, rejected external, non-consensual limits on a state's prerogative to select the tools of international intercourse, including war, that it deemed best suited to achieve its national interests. Although positivism acknowledged that states should exhaust peaceful remedies before resorting to force, once that occurred, the right to use force was essentially unlimited. The sole exceptions were cased bound by bilateral treaties in which the parties had agreed not to settle disputes forcibly.

By the turn of the twentieth century, the legal milieu began to change. The Hague Conventions for the Pacific Settlement of International Disputes of

\footnotetext{
* Michael Schmitt is Professor of International Law at the George C. Marshall European Center for Security Studies, Garmisch-Partenkirchen, Germany.

${ }^{1}$ St. Augustine, Quaestiones in Heptateuchum, Book VI, $10 \mathrm{~B}$.

${ }^{2}$ St. Thomas Aquinas, Summa Theologica, Book II, 40.

${ }^{3}$ Niccolò Machiavelli, The Prince, trans. George Bull (New York: Penguin, 1999), chapter 3.
} 
1899 and of 1907, for instance, provided that, "in case of serious disagreement or conflict, before an appeal to arms, the Signatory Powers agree to have recourse, as far as circumstances allow, to the good offices or mediation of one or more of the friendly Powers." In light of the shocking carnage of the First World War, the 1919 Covenant of the League of Nations tightened the regime governing the use of force by requiring parties to submit disputes to arbitration, judicial settlement, or enquiry by the League's council before resorting to war.

The 1928 General Treaty for the Renunciation of War as an Instrument of National Policy (known as the Kellogg-Briand Pact) imposed even more stringent restriction on signatory states. Indeed, violation of the Pact formed the basis for a number of prosecutions at Nuremberg. Yet, despite "condemn[ing] recourse to war for the solution of international controversies, and renounc[ing] it as an instrument of national policy," the Pact permitted wars of self-defense, was limited to conflicts between signatory states, and allowed the use of force pursuant to international policy, in particular that of the League of Nations. ${ }^{6}$

In the aftermath of the Second World War, it was obvious that a means of enforcement was needed if any prohibition against the use of force was to be effective. The 1945 United Nations Charter sought to fill this void. It remains the keystone in the legal framework governing the resort to force by states. Article 2(4) sets forth the Charter's prohibition of the use of force: "All Members shall refrain in their international relations from the threat or use of force against the territorial integrity or political independence of any state, or in any other manner inconsistent with the Purposes of the United Nations." " Two aspects of this proscription merit comment.

First, not only are uses of force forbidden, but so too are threats to use force. That said, and as noted by the International Court of Justice in its 1996 advisory opinion, "Legality of the Threat or Use of Nuclear Weapons," threats to use lawful force remain permissible. For instance, it is perfectly appropriate to threaten to use force in self-defense; indeed, such threats may well lead to greater international stability by deterring aggression. This point is of particular relevance in light of the U.S. threats to attack Iraq, threats which it carried out in March 2003. The legality of the threats depended not on the actuality of Iraq's possession of weapons of mass destruction or mistreatment of its citizenry. Instead, the only thing that could render the threats legal is an exception to the Article 2(4) prohibition that would justify a U.S. attack. Secondly, the pro-

\footnotetext{
${ }^{4}$ Hague Convention (I) for the Pacific Settlement of International Disputes, 29 July 1899, 32 Stat. 1779, 1 Bevans 230, Article 2. See also Hague Convention (II) for the Pacific Settlement of International Disputes, 18 October 1907, 36 Stat. 2199, 1 Bevans 577.

${ }^{5}$ Covenant of the League of Nations, 28 June 1919, 225 Consolidated Treaty Series 188, Article 2.

${ }^{6}$ See General Treaty for Renunciation of War as an Instrument of National Policy (Kellogg-Briand Pact), 27 August1928, 46 Stat. 2343, TS No. 796, 94 LNTS 57.

${ }^{7}$ Charter of the United Nations, 26 June 1945, Article 2(4); available at http://www.un.org/aboutun/charter/.
} 
hibition extends to any threat or use of force (not simply a seizure of territory or exertion of political dominance) inconsistent with the purposes of the United Nations. According to the Charter, the maintenance of "international peace and security" is its central purpose. ${ }^{8}$ Given the liberality with which the Security Council has characterized situations as threatening international peace, particularly in the last decade, the Article 2(4) prohibition is nearly all-encompassing.

There are two explicit exceptions to Article 2(4) in the text of the Charter. The first is that of authorization by the Security Council of the use of force. It may grant such authority whenever it characterizes a situation, pursuant to Article 39, as a "threat to the peace, breach of the peace, or act of aggression." Note that no actual breach of the peace or act of aggression need have occurred; a mere threat is all that is required.

The Council's discretion to so label a situation is essentially unfettered. Since the end of the Cold War, the Security Council has exercised that discretion with great frequency. Prior to the U.S. operations against Iraq, for example, the Council found "Iraq's non-compliance with Council resolutions and proliferation of weapons of mass destruction and long-range missiles" to constitute a threat to international peace and security. ${ }^{9}$ Less politically charged, and thus more typical, was its April 2003 finding that "the continued flow of weapons and ammunition supplies to and through Somalia from sources outside the country," despite a UN-declared arms embargo, constituted a threat. ${ }^{10}$

Once a situation has met the Article 39 threshold, the Council may consider calling on member states, pursuant to Article 41, to impose "measures not involving the use of armed force," such as an embargo. If those measures prove unsuccessful, or if it determines that they would likely be ineffective, the Security Council may proceed to authorize force under Article 42.

Authorization can be granted in three ways. Increasingly common is a the extension of a mandate to a coalition of the willing. The Interim Security Assistance Force tasked with maintaining order in and around Kabul in the aftermath of Operation Enduring Freedom is a recent example of this approach. Alternatively, the Council can give a mandate to an international organization, such as NATO has received vis-à-vis its ongoing operations in BosniaHerzegovina (SFOR) and Kosovo (KFOR). Lastly, the Council may authorize the creation of a United Nations force, like the United Nations Mission in Sierra Leone, UNAMSIL, created in 1999.

Operating outside this framework is politically risky. The failure of NATO to secure a UN mandate before attacking the Federal Republic of Yugoslavia (now Serbia and Montenegro) in 1999 generated significant con-

\footnotetext{
${ }^{8}$ Ibid., Article 1(1).

${ }^{9}$ Security Council Resolution 1441, U.N. SCOR, 4644th mtg., U.N. Doc. S/RES/1441 (2002); available at http://www.un.org/Docs/scres/2002/sc2002.htm.

${ }^{10}$ Security Council Resolution 1474, U.N. SCOR, 4737th mtg., U.N. Doc. S/RES/1474 (2003); available at http://www.un.org/Docs/sc/unsc_resolutions03.html.
} 
demnation. Similarly, the U.S. decision to attack Iraq with a small coalition of the willing in 2003, despite opposition from many on the Security Council, remains a source of great controversy.

The second exception to the UN Charter's prohibition on the use of force is self-defense. Article 51 stipulates that the Charter does not "impair the inherent right of individual or collective self-defense if an armed attack occurs against a Member of the United Nations." This right is subject to three criteria deriving from the nineteenth-century Caroline affair. That case involved an 1837 raid into the United States by British forces that were attempting to suppress Canadian rebels operating from U.S. territory. In the course of that raid, the Caroline, a vessel used to support the rebel forces, was set ablaze and then sent over Niagara Falls.

In the resulting exchange of diplomatic notes between the Americans and British, Secretary of State Daniel Webster penned what has become the accepted standard for the use of force in self-defense: "a necessity of selfdefense, instant, overwhelming, leaving no choice of means, and no moment for deliberation." Today, it has matured into a requirement that acts of self-defense be necessary, proportional, and immediate. The Nuremberg Tribunal adopted this standard, as has the International Court of Justice. ${ }^{11}$

Necessity requires that forceful defensive reactions be a last resort that peaceful means of resolution be exhausted first. When a state is under attack, the necessity or responding with force is manifest. But when dealing with threats to the peace, the availability of non-forceful options, such as diplomacy or economic sanctions, is a much more complex issue. Given international law's general presumption against the legality of using force (the Charter admits of but two exceptions), there must be a high level of certitude that the threat will be made good and that viable options have been exhausted before using defensive force in the face of a mere threat. Claims that force was legally unnecessary because the Security Council was still deliberating the issue underlie much of the criticism against the 2003 coalition attacks against Iraq.

Proportionality is the second condition for defensive uses of force. This principle is often misconstrued as requiring that a state respond to an attack only with roughly the same degree of force as used against it. For practical reasons, this is an absurd proposition. It could either leave a state effectively defenseless, because greater force is needed to defeat an onslaught, or justify a state's commission of excesses when a lesser degree of force than that used against it would suffice. Instead, proportionate force is properly defined as that amount of force necessary to repel an attack. Framing it in this way reflects the

\footnotetext{
${ }^{11}$ International Military Tribunal (Nuremberg), "Judgment and Sentences," American Journal of International Law 41 (1947); "Military and Paramilitary Activities in and Against Nicaragua," International Court of Justice Reports (1986), para. 176; "Legality of the Threat or Use of Nuclear Weapons," Advisory Opinion No. 95, International Court of Justice Reports (1996), para. 41.
} 
dual objectives of allowing states to effectively defend themselves, while at the same time limiting the extent of violence to which the international community is subjected.

The third requirement, drawn from Webster's "instant" and "leaving no moment for deliberation" language, is imminency, a criterion relevant only in the case of attacks not yet launched. It is intended to delay the resort to force until the last moment, thereby allowing the greatest opportunity for peaceful options to work.

This standard has been interpreted restrictively in decades past ${ }^{12}$ However, a restrictive reading no longer makes sense, given the advent of methods and means of warfare that can have devastating consequences without, in the words of Webster, leaving any moment for deliberation. Examples include attacks by terrorists who emerge from the shadows without warning to strike directly at the civilian population, as occurred on 11 September 2001, and the use of weapons of mass destruction. In such circumstances, balancing of the international community's presumption against the use of force and the right of states to effectively defend themselves unavoidably results in a standard that permits states to react defensively to an impending attack "during the last window of opportunity." This window may close long before the attack is to occur, for example, before a weapon of mass destruction can be transferred to a terrorist group intent on its use. However, this "relaxed" application of the imminency standard in the context of twenty-first-century conflict must be accompanied by a high degree of certainty that the attack will actually occur.

Although Security Council mandates and defensive operations exhaust the textual exceptions to the Article 2(4) prohibition on the threat or use of force, two extra-Charter exceptions are sometimes suggested. The first is the use of force to realize the right to self-determination, which is articulated in numerous instruments, most notably the 1966 International Covenant on Civil and Political Rights ("All peoples" have the right to "determine their political status and freely pursue their economic, social and cultural development" Article 1). As traditionally interpreted, the principle of self-determination bore only on the issue of decolonialization. Today, it enjoys much broader application, but most scholars agree that it does not generally include the right of violent secession. A possible exception, based on state practice, UN pronouncements, and scholarly comment, may exist in the face of gross violation of human rights. Yet, as demonstrated in the Kosovo and Chechnya cases, even in such situations the international community remains hesitant to embrace a principle that allows armed action.

Humanitarian intervention is the second possible extra-Charter exception. Those humanitarian efforts mounted pursuant to a Security Council mandate,

\footnotetext{
${ }^{12}$ Oscar Schacter, “The Right of States to Use Armed Force," Michigan Law Review 82 (1984): 1634-35.
} 
as in Somalia in 1992 (UNITAF and later UNOSOM II), are unquestionably legal. Indeed, the failure of the United Nations to intervene when genocide occurred in 1994 in Rwanda generated widespread condemnation. ${ }^{13}$ It is only when an intervention occurs without Council approval that legality becomes an issue.

In some cases, the United Nations has issued ex post facto approval of a humanitarian operation. For instance, a 1991 Council Presidential Statement "commended" ECOWAS member states (which intervened militarily with ECOMOG) for their 1990 intervention in Liberia. The Council did so again when ECOMOG actions restored stability after further fighting. Similarly, ECOMOG interventions in Sierra Leone following the 1997 overthrow of President Kabbah received after-the-fact praise from the Council. Arguably, these operations signaled the international community's tacit approval of humanitarian interventions in response to humanitarian crises, at least when a regional organization was the intervener.

The Kosovo crisis tested this prospect. Unlike the African cases, NATO intervened in the Federal Republic of Yugoslavia despite opposition from two key members of the Security Council, China and Russia. A number of other states also expressed concern over the legality of Operation Allied Force, as did significant segments of the NGO and scholarly communities. Vastly differing conclusions have been drawn in the process of deconstructing the Kosovo case and comparing it with prior "unmandated" interventions. Despite the differences, it is clear that in assessing future operations, the international community will consider such factors as the scale of human rights violations, the exhaustion of peaceful alternatives to resolve the crisis, the intervener's motivation, the degree of international participation in the operation, and the extent and source of opposition to intervention. Nevertheless, international reactions to Operation Allied Force clearly confirmed the absence of any unequivocal norm permitting armed intervention, even in response to considerable humanitarian suffering.

A number of other bases for the use of force have been suggested, especially since the demise of the bipolarity that bounded the use of force during the Cold War, such as counter-terrorism, efforts to combat WMD development and proliferation, regime change, and preemption. As independent bases, virtually all amount to lex ferenda at best. However, certain of them could fall within the ambit of the existing jus ad bellum.

Most significantly, counter-terrorist operations are most soundly based on the law of self-defense. Indeed, the international community almost universally supported U.S. and coalition operations launched against al Qaeda and the Taliban in October 2001. Today there is no question that Article 51 of the Charter extends to attacks conducted by non-state actors, particularly terrorists.

${ }^{13}$ See Ingvar Carlsson, Han Sung-Joo, and M. Kupolati, Report of the Independent Inquiry into United Nations Actions during the 1994 Rwanda Genocide, 15 December 1999. Text is at http://www.ess.uwe.ac.uk/documents/RwandaReport1.htm. 
Recent state practice has noticeably shaped the present understanding of self-defense. With regard to the imminency requirement, it has demonstrated the acceptability of treating a series of terrorist acts as a single, continuous campaign, such that imminency is no longer relevant once the initial attack is launched. In other words, if a terrorist group strikes with sufficient force to constitute an "armed attack" under Article 51, the victim state may respond with armed force in self-defense until the group no longer poses a serious risk of further attacks. The international support for Operation Enduring Freedom in Afghanistan also reveals that the necessity requirement does not require that a response to terrorism be carried out purely within the realm of law enforcement. If law enforcement is uncertain to prove effective in foiling future attacks, then it is legally "necessary" to escalate the response to the level of armed force.

Moreover, the complete lack of condemnation of coalition attacks directly against the Taliban - the de facto government of Afghanistan - during Operation Enduring Freedom demonstrates that the international community's tolerance for state support of terrorism is dropping precipitously. While the strikes might not have complied with the pre-September 11 jus ad bellum regarding forceful responses to state sponsorship of terrorism, that standard has evolved in a progressively permissive direction. In particular, international law now clearly permits a state to cross into another for the limited purpose of combating terrorists when the state in which the terrorists are based does not or cannot put an end to terrorist use of its territory.

The existence of weapons of mass destruction has also been asserted as justifying the use of force against those who possess them. On multiple occasions, the United States and the United Kingdom put forward Iraq's development and possession of WMD as one of the legal justifications for Operation Iraqi Freedom, their combined attack on Iraq. ${ }^{14}$ The WMD issue also plays a prominent role in U.S. policy pronouncements, including the National Strategy for Combating Terrorism articulated by the Bush Administration in 2003.

If counter-WMD operations comport with the aforementioned requirements of self-defense, they are normatively proper. In particular, there must be a high degree of certainty that such weapons will be used against the state countering them, and the counter-WMD operations can occur only during the last viable window of opportunity to prevent attack. Operations against a speculative threat or those that ignore viable peaceful alternatives for resolving the threat are illegal. On the other hand, the last window of opportunity to prevent the use of WMD may close long before that intended use was to take place, especially if transfer of the weapons to a terrorist group is underway.

Another independent basis occasionally suggested for the use of force is regime change. Regime change may occur as a consequence of an otherwise

${ }^{14}$ Authorization for the Use of Military Force Against Iraq, Resolution of 2002, Pub. L. No. 107243, 116 Stat. 1498, 1499, 1501. 
lawful use of armed force, such as self-defense or, perhaps, humanitarian intervention; if so, it is legal. However, regime change alone as a justification for using force finds no basis in international law, except when conducted with the clear authorization of the Security Council. Some commentators have claimed that forceful regime change to impose democracy might be appropriate..$^{15}$ This assertion finds little support in state practice. "Forced democratization" is only legal if the Security Council grants a mandate for that purpose, as it did in 1994 to return democratically elected President Jean-Bertrand Aristide to office in Haiti following a military coup.

Finally, the U.S. National Security Strategy, issued in 2002, set out a strategy of preemption that evoked great controversy and criticism. Specifically, it stated that:

We must adapt the concept of imminent threat to the capabilities and objectives of today's adversaries. Rogue states and terrorists do not seek to attack us using conventional means. They know such attacks would fail. Instead, they rely on acts of terror and, potentially, the use of weapons of mass destruction - weapons that can be easily concealed, delivered covertly, and used without warning....

The United States has long maintained the option of preemptive actions to counter a sufficient threat to our national security. The greater the threat, the greater is the risk of inaction - and the more compelling the case for taking anticipatory action to defend ourselves, even if uncertainty remains as to the time and place of the enemy's attack. To forestall or prevent such hostile acts by our adversaries, the United States will, if necessary, act preemptively. ${ }^{16}$

Critics alleged that a preemptive strategy complies with neither the necessity criterion, because all avenues of deterring a threat would not have been exhausted, or that requiring imminency, because preemption would occur before the threat was "instant, overwhelming, leaving no choice of means, and no moment for deliberation." In fact, the strategy is neither exclusively consistent nor inconsistent with the law of self-defense. Some preemptive actions might be premature, while others might occur during the last window of opportunity to prevent an attack and when only force can address the situation. In other words, criticism should be leveled not at the strategy itself, but rather at applications of it that do not comport with existing international law.

In summary, while reports of the death of the jus ad bellum are clear-

\footnotetext{
${ }^{15}$ Thomas Wingfield, "Taking Aim at Regime Elites: Assassination, Tyrannicide, and the Clancy Doctrine," Maryland Journal of International Law and Trade 22 (1999).

16 "The National Security Strategy of the United States of America,"September 2002, 15-16; available at http://www.whitehouse.gov/nsc/nss.pdf.
} 
ly exaggerated, the last decade has witnessed dynamic evolution in the normative architecture governing the use of force.${ }^{17}$ Further progressive development is to be anticipated, particularly as threats to global security - especially terrorism, weapons of mass destruction, and cyber-war - themselves evolve. Nevertheless, the core strictures of the jus ad bellum have proven adequately flexible to adapt to the security context of the time. They are likely to remain so for the foreseeable future.

${ }^{17}$ See Michael J. Glennon, "Why the Security Council Failed," Foreign Affairs 82:3 (May/June 2003): 16-35. 


\section{Bibliography}

Aquinas, St. Thomas. Summa Theologica. Vol. Book II., 1274.

Augustine, St.. Quaestiones in Heptateuchum. Vol. Book VI., 420.

Carlsson, Ingvar, Han Sung-Joo, and M. Kupolati. Report of the Independent Inquiry into United Nations Actions during the 1994 Rwanda Genocide., 1999.

Charter of the United Nations., 1945.

Covenant of the League of Nations In 225 Consolidated Treaty Series., 1919.

General Treaty for Renunciation of War as an Instrument of National Policy (Kellogg-Briand Pact)., 1928.

Glennon, Michael J.. "Why the Security Council Failed." Foreign Affairs 82, no. 3 (2003): 16-35.

Hague Convention (I) for the Pacific Settlement of International Disputes., 1899.

Judgment and Sentences. American Journal of International Law 41 (1947).

Legality of the Threat or Use of Nuclear Weapons In International Court of Justice Reports., 1996.

Machiavelli, Niccolo. The Prince. London: Penguin, 1968.

Military and Paramilitary Activities in and Against Nicaragua In International Court of Justice Reports., 1986.

Schacter, Oscar. "The Right of States to Use Armed Force." Michigan Law Review 82 (1984): 1634-35.

Security Council Resolution 1441 In U.N. SCOR, 4644th mtg., 2002.

Security Council Resolution 1474 In U.N. SCOR, 4737th mtg., 2003.

The National Security Strategy of the United States of America., 2002.

Wingfield, Thomas. "Taking Aim at Regime Elites: Assassination, Tyrannicide, and the Clancy Doctrine." Maryland Journal of International Law and Trade 22 (1999). 